Оригинални научни рад

339.54:061.1(100)]:340.132

doi:10.5937/zrpfns52-19362

Rodoljub M. Etinski, Ph.D., Full Professor

University of Novi Sad

Faculty of Law Novi Sad

R.Etinski@pf.uns.ac.rs

\title{
A CRITICAL REVIEW OF INTERPRETATION OF ARTICLES III AND XX OF THE GATT 1994
}

Abstract: Textual interpretation is the prevailing mode of interpretation. Significant exceptions exist. The choice of means of interpretation and the different weight attributed to them can shape the outcome of interpretation. Different means applied to the same term can sometimes create different clarifications. Moving decisive significance from one to another means can occasionally change the outcome of interpretation. There are many factors that determine the choice and weight of the means of interpretation. The spirit, as originates from the object and purpose of the GATT 1994, might be in the background of all of them. The interpretation does not operate without certain inconsistencies and difficulties.

Keywords: interpretation, the GATT 1994, national treatments, exceptions.

\section{INTRODUCTION}

The text is focused on the interpretation of Articles III and XX of the 1994 General Agreement on Tariffs and Trade (hereinafter: the GATT 1994). ${ }^{1}$ Article III secures national treatment of imported products regarding internal taxation and non-fiscal regulation. Article XX allows certain general exceptions of substantive provisions of the GATT 1994. The analysis of interpretation of Article III is limited to paragraphs 2 and 4. Paragraph 2 relates to fiscal measures. Paragraph 4 governs non-fiscal regulation. The two Articles are chosen due to the characteristics of their provisions that may be relevant for the choice of means of interpretation. ${ }^{2}$

\footnotetext{
${ }^{1}$ This research has been rendered in the framework of the research project "Legal Tradition and New Legal Challenges" financed by Novi Sad Faculty of Law.

2 Andreas Sennekamp, Isabelle Van Damme, A Practical Perspective on Treaty Interpretation: The Court of Justice of the European Union and the WTO Dispute Settlement System, Cambridge Journal of International and Comparative Law 3/2014, 499.
} 
The analysis is constrained to a small number of provisions, but it intends to undertake a thorough exploration. It appears, however, that most disputes relate to these very provisions.

The interpretation might be defined as collating legal information from relevant sources to reply to questions that the parties submitted to the panels and the Appellate Body. ${ }^{3}$ There is a main question or a few main questions relating to the compatibility of a national provision with the provisions of the GATT 1994. The main question is usually disassembled during the process of interpretation in more specific questions. Thus, for example, in $U S$ - Gasoline the question submitted to the Panel was whether some provisions of the Clean Air Act were compatible with, inter alia, Article III:4 and Article XX (b), (d) and (g) of the GATT 1994? An answer to the main question required replies to more specific questions, such as whether imported gasoline and domestic gasoline were like products, ${ }^{4}$ and whether no less favourable treatment must be provided regarding the products or regarding the producers of the products. ${ }^{5}$

Usually, interpretation is defined as a clarification of the meaning of a provision. Also, usually, the clarification serves in the resolution of a dispute. However, looking at Article 3 (2) of the Understanding on Rules and Procedures Governing the Settlement of Disputes (hereinafter: the Understanding on Rules and Procedures) and at the interpretative practice of the DSB, it can be observed that the Appellate Body does not interpret a provision exclusively to resolve a dispute, but also to deliver a clarification as the building element of the "GATT acquis." 6

Interpretation of the GATT and other covered agreements has attracted attention of the writers. ${ }^{7}$ J. Klabbers argues that interpretation is a political act which

${ }^{3}$ Rodoljub Etinski, Means of Interpretation of International Treaties and Determinants of Their Significance, Proceedings of Novi Sad Faculty of Law 4/2017, 1182.

${ }^{4}$ Panel Report, United States - Standards for Reformulated and Conventional Gasoline, WT/ DS2/R, 29 January 1996 (US - Gasoline), para. 6.7.

${ }^{5}$ Ibid., para. 6.11 .

${ }^{6}$ P. Lamy, Place of the WTO and its Law in the International Legal Order, European Journal of International Law 5/ 2007, 972.

7 Jan Klabbers, On Rationalism in Politics: Interpretation of Treaties and the World Trade Organization, Nordic Journal of International Law, 2005, 405 - 428; Bradly J. Condon, Lost in Translation: Plurilingual interpretation of WTO Law, Journal of International Dispute Settlement, Vol. 1, No. 1 (2010), 191 - 216; Bryan Mercurio, Mitali Tyagi, Treaty Interpretation in WTO Dispute Settlement: The Outstanding Question of the Legality of Local Working Requirements, Minnesota Journal of International Law,2010, 275 - 326; Isabelle Van Damme, Treaty Interpretation by the WTO Appellate Body, The European Journal of International Law, 3/2010, 605 - 648; Riccardo Pavoni, Mutual Supportiveness of Interpretation and Law-Making: A Watershed for the 'WTO-and-Competing - Regimes' Debate, The European Journal of International Law, 3/2010, 649 - 679; Gregory Shaffer; Joel Trachtman, Interpretation and Institutional Choice at the WTO, Virginia Journal of International Law, 2011, 103 - 153; George Nolte, Subsequent Practice as a Means of Interpretation in the Jurisprudence of the WTO Appellate Body, in The Law of Treaties beyond the Vienna Convention, ed. E. Cannizzaro, Oxford, 2011, 138 - 144; Chang-fa Lo, The 
cannot be tamed by strict rules of interpretation. He asserts: "whoever controls the interpretation of a treaty controls the scope of rights and obligations." 8 According to two other authors, the DSB was created to "judicialize dispute resolution, making it rules-based rather than controlled by politics." The two different opinions are not necessary irreconcilable. However, it is very probable that the WTO Members would like to know what they can expect from the DSB. Unpredictability and uncertainty are enemies of international trade.

There is a large scale of factors that can determine the interpretative practice of courts and tribunals. J. Pauwelyn and M. Elsig suggested that the interpretative choices are determined by the interaction of two variables: "interpretation space that is made available to a tribunal" and "interpretation incentives defined as intrinsic motivations of a tribunal's members". ${ }^{10}$ An interpretative space includes specific directions on interpretation in a treaty; "clarity and precision of obligations"; legal and factual potentials of the parties concerning interpretation etc. Under "interpretation incentives" the authors comprehend institutional features, like permanency of a tribunal, audience of interpretation, personal hermeneutical ideology of judges, acquiring by a tribunal of status of "a reputation as a legitimate platform" etc. ${ }^{11}$

By comparing institutional circumstances of the European Court of Justice and the DSB, A. Sennekamp and I. Van Damme refer to the size of institution, caseload, the way of handling individual cases, the legal and institutional environment in which the body operates, completeness and precision of treaty provisions and the internal procedure of the body etc. ${ }^{12}$

This critical review of interpretation of the two Articles includes an analysis of the main and exceptional interpretative approaches. It explores how the choice of means of interpretation and the significance attached to them in specific cases determine the outcome of interpretation. Other factors that can shape interpretation are investigated. A possible interpretative deadlock has been noted that might be a consequence of over-interpretation. An odd resolution of the contradiction between the preparatory work and the text is discussed. The text begins by reflecting on certain insufficiencies of the general rules on interpretation of international treaties that leave broad discretion to interpreters. The factors expected

Difference between Treaty Interpretation and Treaty Application and the Possibility to Account for NONWTO Treaties during WTO Treaty Interpretation, Indian International and Comparative Law Review, 1/2012, 1 -25.

8 J. Klabbers, op. cit., 426. supra note 7.

${ }^{9}$ A. Sennekamp, I. Van Damme, op.cit., 495. supra note 2.

${ }^{10}$ See Joost Pauwelyn, Manfred Elsig, The Politics of Treaty Interpretation: Variations and Explanations Across International Tribunals, electronic copy available at: http://ssrn.com/abstract= 1938618; A. Sennekamp, I. Van Damme, op.cit., 489-507.

${ }^{11}$ See J. Pauwelyn, M. Elsig, op. cit.; A. Sennekamp, I. Van Damme, op.cit., 489-507.

${ }^{12}$ A. Sennekamp, I. Van Damme, op. cit., 499. supra note 2. 
to determine the choice and weight of means of interpretation of the two Articles are then presented. The main part of the text continues with a detailed analysis of interpretation of the provisions of the two Articles.

An exploration of the interpretation of Article III: 2 and 4 considers the following items: determination of general interpretative approach; importance of the choice of means of interpretation regarding interpretation of the term "like"; significance attributed to various means of interpretation regarding the interpretation of the clause "directly competitive and substitutable products"; the breadth of meaning can be shaped by the combination of means of interpretation; judicial activism in interpretation of the terms "like products"; correct and wrong application of means of interpretation; assessment of facts and interpretation; and interpretative explanations.

An investigation of the interpretation of Article XX includes the following issues: textual interpretation as the basic approach; an excursion beyond textual interpretation regarding interpretation of "exhaustible natural resources"; return to textual approach in interpretation of the chapeau of Article XX; other departures from textual approach and the problem of over-interpretation; the nature of the objective of a provision and interpretation; an odd resolution of the conflict between the preparatory work and the text in interpretation of the clause "arbitrary or unjustifiable discrimination"; and the application of the principle of reasonableness in interpretation of the term "necessary".

\section{INSUFFICIENCIES OF GENERAL RULES ON INTERPRETATION}

The main instruction concerning the interpretation of the GATT 1994 and other covered agreements of the WTO is laid down in Article 3 (2) of the Understanding on Rules and Procedures. The second sentence of the Article states that the dispute settlement system of the WTO "serves ... to clarify the existing provisions of those (covered) agreements in accordance with customary rules of interpretation of public international law." It is generally accepted, and it is also recognized by the panels and the Appellate Body that Articles $31-33$ of the Vienna Convention on the Law of the Treaties (hereinafter: the VCLT) reflect customary rules on interpretation of international treaties. ${ }^{13}$

Articles $31-33$ consists of a set of instructions about sources that have to be consulted and methods that have to be applied for extracting information relevant for replying to a submitted question. Article 31, under the title "General rule

${ }^{13}$ I. Van Damme, op. cit., 608. supra note 7. See there a list of cases where the Appellate Body confirmed that Articles $31-33$ of the VCLT expresses customary rules. G. Shaffer; J. Trachtman, op. cit., 114- 118. supra note 7. 
on interpretation" determines in an exhaustive way the sources that have to be consulted and the methods that have to be applied. Article 32, under the title "Supplementary means of interpretation," indicates in an exemplary way some supplementary means of interpretation and defines conditions under which they can be utilized. Article 33 is dedicated to differences that can appear between various linguistic versions of a treaty.

Article 31 of the VCLT indicates thus the sources and the methods which have to be used for obtaining information for answering a question. The sources include: the text of a provisions of a treaty; the text of the treaty as whole, including the preamble and annexes; other agreements or unilateral acts rendered at the time of the conclusion of the treaty and which related to the treaty; subsequent agreements on the application and interpretation of a treaty; subsequent practice in application of the treaty that reflects uniform understanding of all parties; and other relevant rules of international law applicable between parties. The methods cover the principle of good faith; attributing an ordinary meaning to a term; establishing the meaning in the context and in light of object and purpose of the treaty; and ascribing a specific meaning to a term if parties intended that. The principle of good faith is complex and includes other principles as the principle of effectiveness and the principle of reasonableness. The principle of effectiveness appears in two variants. The first requires that interpretation has to be performed in a way to enable fulfillment of purposes intended by the parties. The second, known as l'effet utile, asks that all terms in the text have to be taken into account in interpretation. The indicated sources and methods can be marked under the common name "means of interpretation". Article 32 enumerates the preparatory work (travaux préparatoires) and the circumstances of the conclusion of a treaty as a supplementary means and leaves the list of supplementary means open.

Articles 31 and 32 of the VCLT are composed by the International Law Commission (hereinafter: the ILC) in a way to harmonize three basic interpretative approaches: textual, intentional and teleological. The textual and intentional approaches see interpretation as giving effect to the intention of the parties, but they differ in respect to the question as to where to search for intention. ${ }^{14}$ The textual approach takes the text of a treaty as the main source of information on the intention of the parties. The intentional approach is equally ready to consult other sources beyond the text. By emphasizing the object and purpose of a treaty, the teleological approach connects textual and intentional approaches.

Articles 31 and 32 determine some means of interpretation, but they do not inform in relation to the modes of their application, or in other words how these

${ }^{14}$ See about these approaches by Sir Gerald Fitzmaurice, The Law and Procedures of the International Court of Justice 1951 - 4: Treaty Interpretation and Other Treaty Points, The British Yearbook of International law, 1957, $204-209$. 
means have to be applied. Information that can be derivate from the text of Articles 31 and 32 and the preparatory work are not enough to answer all questions relating to the process of interpretation. When there are more available means of interpretation, which then have to be applied? All or some of them? When more means are applied and when they extend contrary information relevant for a reply to the question, how to resolve the problem? These issues are important, and it will be shown later in the text that they can determine the outcome of interpretation.

The preparatory work, that is the texts of the ILC provide some information. The text of Article 31 is structured in four paragraphs. Replying to the comments of the States in 1966, the ILC explained that the four paragraphs structure did not indicate a hierarchical order of means of interpretation and that all of them had to be used so that an interaction among them lead to a legal interpretation. ${ }^{15}$ The ILC states that " $[\mathrm{A}] 11$ the various elements, as they were present in any given case, would be thrown into the crucible, and their interaction would give the legally relevant interpretation." ${ }^{16}$ However, it is not of great help for resolving a disharmony of opposite information flowing from two means of interpretation. When conflicting information coming from two means cannot be reconciled, how to resolve the disharmony, to which of them to give priority? Whether the object and purpose of a treaty should have a decisive role as it is foreseen by Article 33 (4) for the case of linguistic difference? The conditions for application of supplementary means of interpretation, as they are formulated in Article 32, imply certain supremacy of means indicated in Article $31 .{ }^{17}$ However, the ILC noted that means from Article 31 and means from Article 32 have not been divided by a rigid line. ${ }^{18}$

That open issue is not the only problem that burdens interpretation of international treaties. Usually, the international courts and arbitral tribunals do not follow the recommendation of the ILC to consult all available sources and to apply all methods as they are indicated in Article 31 . The courts and tribunals usually choose and apply some means of interpretation, they do not apply all available means. In the case of conflict between two means, they can give priority to one of them by their own choice. Thus, an outcome of interpretation depends more on the choices made by the court rather than of the rules on interpretation. Behaving in such a way, judges provide themselves with great discretion in process and they can make decision that are dressed in the cloth of rules of interpretation, but which are motivated

${ }^{15}$ Report of the ILC on the work of its eighteenth session, Geneva, 4 May - 19 June 1966, The Yearbook of International Law Commission 2/1966, 219, para 8. See about the work of the ILC on codification of the rules by Rodoljub Etinski, Means of Interpretation and Their Interrelationship, Proceeding of Novi Sad Faculty of Law, 1/2016, 9 - 36.

${ }^{16}$ Report of the ILC, op. cit., 219, para. 8. supra note 15.

${ }^{17}$ Ulf Linderfalk, Is the Hierarchical Structure of Articles 31 and 32 of the Vienna Convention Real or Not? Interpreting the Rules of Interpretation, Netherlands International Law Review, 2007, $133-154$.

${ }^{18}$ Report of the ILC, op. cit., 210, para. 10. supra note 15. 
by other factors. ${ }^{19}$ It will be seen later in the text that members of the panels and the Appellate Body make choices that determine results of interpretation.

In the last few years, the ILC has taken some steps forward regarding these issues. Exploring subsequent agreements on the application or interpretation of a treaty and subsequent practice in the application of a treaty since 2014, the ILC has come back to the issue of the relationship of the means of interpretation. The ILC states now that the interpretation has to be performed "as a single combined operation, which places appropriate emphasis on the various means of interpretation". ${ }^{20}$ According to the ILC, an interpreter is not free to choose how to use different means of interpretation, but is expected to ascertain the relevance of different means in a specific case by weighing them in good faith and thus establishing their mutual interaction. ${ }^{21}$ An interpreter is advised by the ILC that in the assessment of relevance and weight of a particular means to follow previous practice in the same or of another area.

\section{THE FACTORS EXPECTED TO DETERMINE THE CHOICE AND WEIGHT OF MEANS OF INTERPRETATION OF THE GATT 1994 AND IN PARTICULAR ARTICLE III: 2 AND 4 AND ARTICLE XX}

There are several factors that can be expected to influence the choice and weight of means of interpretation. The first among them is Article 3 (2) of the Understanding on Rules and Procedures. The first sentence of the Article states that: "The dispute settlement system of the WTO is a central element in providing security and predictability to the multilateral trading system". No doubt the provisions directs toward sources that are conducive to predictability, such as the text of Articles, the text of GATT 1994 as whole, case law and methods such as the ordinary meaning and the context. Other sources, such as practice in the application of the GATT 1994, the relevant rules of international law applicable between the parties or comparative international practice leave broader interpretative space and decrease predictability in interpretation. It will be shown later in the text that the Appellate Body has established the concept of certainty and predictability as a controller of interpretation.

The third sentence of Article 3 (2) of the Understanding on Rules and Procedures is also of determinative value and reads: "[R]recommendations and rulings

${ }^{19}$ H. Lauterpacht, Restrictive Interpretation and the Principle of Effectiveness in the Interpretation of Treaties, British Yearbook of International Law, 1949, 53. Andrea Bianchi, The Game of Interpretation in International Law in A. Bianchi, D. Peat and M. Windsor, (eds.) Interpretation in International Law, 2015, 44. J. Pauwelyn, M. Elsig, op. cit. supra note 10.

${ }^{20}$ Report of the International Law Commission 2016, 120, para. 16.

${ }^{21}$ Ibid., 131, para. 15. 
of the DSB cannot add to or diminish the rights and obligations provided in the covered agreements". Such a sentence makes almost inconceivable an interpretative approach, used for example by the European Court of Human Rights that considers the subsequent practice of the parties in the application of the Convention or worldwide trends to determine a scope of rights and freedoms. ${ }^{22}$ However, it will be presented later in the text that the nature of some provisions of Article XX require a similar interpretative approach.

The same message has been sent by Article IX:2 of the Agreement establishing the World Trade Organization (hereinafter: the WTO Agreement). It states that the Ministerial Conference shall adopt a decision on the interpretation of the covered agreements by a three-fourths majority of the Members and that the interpretation shall not be used to undermine the amendment procedure in Article X. The general rule of voting requires that the majority of votes be cast. By requiring a qualified majority and by warning that the procedure of interpretation should not be misused for amending the covered agreement, the Members inform that they expect strict textual interpretation. Thus, judicial activism in interpretation is not expected. Again, the later text shows that judicial activism is not absent in interpretation of some terms.

There is an occasion where the Members expressed their tolerance for a kind of much looser interpretation. Article 17 (6) (ii) of the Anti-Dumping Agreement states: "where the panel finds that a relevant provision of the Agreement admits of more than one permissible interpretation, the panel shall find the authorities' measure to be in conformity with the Agreement if it rests upon one of those permissible interpretations". The strict textual interpretation can result in two different interpretations, as it is visible in many cases when the Appellate Body corrects an interpretation of the panel. However, the text of Article 17 (6) (ii) of the Anti-Dumping Agreement induces the panel to see whether there are more permissible interpretations. It is not the case with interpretation of other provisions.

The next factor that can influence the choice of means of interpretation is the procedure of dispute settlement. The panel sends the interim report to the parties which comment on it and the panel replies to the comments. The effect of that procedural step to interpretation has become evident very early. Commenting on the interim report, which the Panel sent to the parties in US - Gasoline, the United States objects, inter alia, that the Panel uses specific terms which do not appear in the text of provisions of Article XX (b) and (d). The Panel accepts the objection and revises corresponding paragraphs of the Report. ${ }^{23}$ Obviously, eventual interpretative excursions of the panel beyond the terms used in a provision

${ }^{22}$ See such interpretative approach in Magyar Helsinki Bizottság v. Hungary, App. no. 18030/11, Judgment of 8 November 2016., para 125, or in Christine Goodwin v. The United Kingdom, App. no. 28957/95, Judgment of 11 July 2002, para. 74.

${ }^{23}$ Panel Report, US - Gasoline, paras. 5.3, 5.4. 
can face objections of the parties. It is a factor that can stimulate the panel to adhere strictly to the text. The report of the panel, including interpretation, can be revised by the Appellate Body. That is one of the reasons why interpretative findings of the Appellate Body has become interpretative guidance for the panels.

Article III: 2 and 4 secures national treatment regarding fiscal regulation and other regulations. Article XX provides the general exceptions. They differ by their objects. The substance of Article III: 2 and 4 is a comparison of treatment of imported and domestic products. By its subject-matter it is limited to international trade law. Article XX allows general exceptions from other substantive provisions of the GATT 1994 for satisfaction of some non-trading needs, like protection of public morals, life and health, exhaustible natural resources etc. Thus, the Article goes beyond international trade law and touches other legal fields like environmental law. It might be expected that interpretation of Article III: 2 and 4 remains in the domain of strict textual interpretation and that the interpretation of Article XX involves sources and methods beyond strict textual interpretation.

Having in view that the subject-matter of interpretation remains the same, it can be expected that over time the importance of case law or the "GATT acquis," increases.

\section{MEANS AND MODES OF INTERPRETATION OF ARTICLE III:2 AND 4}

\subsection{A textual interpretation as the general approach}

Article III of GATT 1994, under the title "National Treatment on Internal Taxation and Regulation" consists of 10 paragraphs. The first paragraph expresses the general principle of national treatment. The second paragraph is dedicated to internal taxes and other fiscal regulation and the fourth paragraph is related to internal non-fiscal regulation. The purpose of the Article is to secure equal fiscal and non-fiscal treatment for imported and domestic products.

Early in 1996, the Appellate Body in Japan - Alcoholic Beverage II, one among the first cases under the GATT 1994 in 1996, defined the general interpretative approach in the following way: "The terms of Article III must be given their ordinary meaning -- in their context and in the light of the overall object and purpose of the WTO Agreement. Thus, the words actually used in the Article provide the basis for an interpretation that must give meaning and effect to all its terms. The proper interpretation of the Article is, first of all, a textual interpretation." 24

${ }^{24}$ Appellate Body Report, Japan - Taxes on Alcoholic Beverages, WT/DS 8, 10, 11/AB/R, 4 October 1996, (Japan - Alcoholic Beverages II), p. 17, f. 39, p. 24, f. 52. Panel Report, India - 
The textual interpretation, as defined in the quoted passage above, relies on the words actually used and the methods of ordinary meaning, context, object and purpose of the WTO Agreement and l'effet utile. The interpretative practice related to Article III: 2 and 4 shows that the sources of information, which the panels and the Appellate Body have normally utilized, are the text of the Article, the interpretative Note attached to the Article and case law. In a small number of cases the WTO Agreement was consulted. Other sources, such as negotiating history ${ }^{25}$ or comparative practice ${ }^{26}$ have been employed only in exception.

The interpretative note attached to Article III, titled as the Note Ad Article III, or just $A d$ Article III, plays an important role in the interpretation of the Article. It has qualified some terms in the text of Article III. Thus, the terms "imported or domestic products" in the second sentence of Article III:2 have been specified by a requirement in paragraph 2 of Note $A d$ Article III that they have to be "directly competitive or substitutable products". The Appellate Body observes that provisions of the Article and "the accompanying Ad Article have equivalent legal status in that both are treaty language which was negotiated and agreed at the same time." 27 The interpretative notes are annexes to the GATT and Article XXXIV of the GATT determines them to be an integral part of the Agreement.

The Panels and the Appellate Body operate various methods to find information relevant for answers in the numbered texts. They use the ordinary meaning method ${ }^{28}$ and dictionaries ${ }^{29}$ to establish the ordinary meaning, the context of a provision, ${ }^{30}$

Measures Affecting the Automotive Sector, WT/DS 146, 175/ R, 21 December 2001, (India-Autos), para. 7.169.

${ }^{25}$ Appellate Body Report, Japan - Alcoholic Beverages II, p. 17. Panel Report, Korea Taxes on Alcoholic Beverages, WT/DS 75, 84/ R, 17 September 1998, (Korea-Alcoholic Beverages), paras. $10.38,10.39$.

${ }^{26}$ Panel Report, Korea - Alcoholic Beverages, para. 10.81.

27 Appellate Body Report, Japan - Alcoholic Beverages II, p. 24. Panel Report, KoreaAlcoholic Beverages, f. 346. Panel Report, Chile - Taxes on Alcoholic Beverages, WT/DS 87, 110/ R, 15 June 1999 (Chile - Alcoholic Beverages), f. 349.

${ }^{28}$ Appellate Body Report, Korea - Taxes on Alcoholic Beverages, WT/DS 75, 84/ AB/R, 18 January 1998, (Korea - Alcoholic Beverages), para. 114. Panel Report, Japan - Taxes on Alcoholic Beverages, WT/DS 8, 10, 11/R, 11 July 1996, (Japan - Alcoholic Beverages II), para. 6.28. Panel Report, Canada - Certain Measures Affecting the Automotive Industry, WT/DS 142/ R, 11 February 2000, (Canada - Autos), paras. 10.80, 10.107. Panel Report, US - Gasoline, para. 6.12. Panel Report, India - Autos, para. 7.181.

${ }^{29}$ Appellate Body Report, United States - Standards for Reformulated and Conventional Gasoline, WT/DS2/AB/R, 29 April 1996, (US-Gasoline) p. 20. f. 40, 41. Appellate Body Report, (Korea-Alcoholic Beverages), p. 25, f. 67, p. 32, f. 89, 90. Panel Report, (India-Autos), para. 7.181. Panel Report, Canada - Autos, para. 10.107, f. 857.

${ }^{30}$ Appellate Body Reports, Korea - Alcoholic Beverages, paras. 116, 117, Japan - Alcoholic Beverages II, pp. 18, 24. Panel Report, Argentina - Measures Affecting the Export of Bovine Hides and the Import of Finished Leather, WT/DS155/R, 19 December 2000 (Argentina - Hides and Leather), paras. 11.169. Appellate Body Report, European Communities - Measures Affecting 
the object and purpose of the WTO Agreement, ${ }^{31}$ the object of the GATT 1994, ${ }^{32}$ purpose of the Article, ${ }^{33}$ object and purpose of the first sentence of Article III:2. ${ }^{34}$ The principle of effectiveness, ${ }^{35}$ the consistency with case law under GATT 1947 and under GATT $1994^{36}$ and the grammatical method ${ }^{37}$ are also applied.

Strict adherence to the text is visible in the first step of the application. The first step frequently consists of the disassembling of the text of a paragraph by separating its main elements. Thus, for example, in EC-Seal Products the Appellate Body quotes Article III: $4^{38}$ and then splits the text in to three separate elements. ${ }^{39}$

\subsection{The importance of the choice of means of interpretation regarding an interpretation of the term "like"}

The importance of the choice of means of interpretation is obvious in the interpretation of the term "like" in Article III:4 in US - Gasoline and later cases. The term appears in paragraphs 2 and 4 of Article III. The application of different

Asbestos and Asbestos-Containing Asbestos Products Asbestos, WT/DS135/AB/R, 12 March 2001. (EC-Asbestos), para. 94. Panel Report, India - Autos, paras. 7.155, 7.170, f. 383. Panel Report, Canada-Autos, para. 10.107. Appellate Body Report, EC - Seal Products, para. 5.114. Panel Report, Japan - Alcoholic Beverages II, para. 6.20.

${ }^{31}$ Appellate Body Report, Japan - Alcoholic Beverages II, pp. 17, 18.

${ }^{32}$ Ibid., p, 25.

${ }^{33}$ Appellate Body Reports, Korea - Alcoholic Beverages, para. 119, Japan - Alcoholic Beverages II, p. 16.

${ }^{34}$ Appellate Body Reports, Japan - Alcoholic Beverages II, p. 19, Korea-Alcoholic Beverages, para. 44. Panel Report, Argentina - Hides and Leather, para. 11.182

35 Appellate Body Report, Japan - Alcoholic Beverages II, p. 18. Panel Report, Brazil Taxation, para. 7.63 .

${ }^{36}$ Appellate Body Report, Japan - Alcoholic Beverages II, p. 20. f. 46. Panel Report, US Gasoline, para. 6.8. Panel Report, Korea - Measures Affecting Imports Fresh, Chilled and Frozen Beef, WT/DS161, 169/R 31 July 2000, (Korea-Various Measures on Beef), paras. 623 - 626. Panel Report, Japan - Measures Affecting Consumer Photographic Film and Paper, WT/DS44/R, 31 March 1998, (Japan - Film), paras. 10.374 - 10.376. Panel Report, Canada - Autos, paras. 10.106-10.107.

${ }^{37}$ Appellate Body Report, Korea - Alcoholic Beverages, para. 117.

${ }^{38}$ Article III: 4 reads: "The products of the territory of any Member imported into the territory of any other Member shall be accorded treatment no less favourable than that accorded to like products of national origin in respect of all laws, regulations and requirements affecting their internal sale, offering for sale, purchase, transportation, distribution or use..."Appellate Body Report, European Communities - Measures Prohibiting the Importation and Marketing of Seal Products. WT/DS400, 401/AB/R, 22 May 2014 (EC - Seal Products), para. 5.98.

${ }^{39}$ It has been done in the following way: "There are three elements that must be demonstrated to establish that a measure is inconsistent with Article III:4: (i) that the imported and domestic products are 'like products'; (ii) that the measure at issue is a 'law, regulation, or requirement affecting the internal sale, offering for sale, purchase, transportation, distribution, or use' of the products at issue; and (iii) that the treatment accorded to imported products is 'less favourable' than that accorded to like domestic products." Ibid., para 5.99. 
means has resulted in different meanings. In $U S$ - Gasoline the Panel refers to Article 31 of the VCLT and cites its first paragraph. ${ }^{40}$ It applies also Article 31 (3, b) of the VCLT. Relying on the first paragraph of Article 31, the Panel determines ordinary meaning of the term "like," which is "similar" or "identical". ${ }^{41}$ The practice of the contracting parties in the application of the GATT 1947, as a means of interpretation defined in Article 31 (3, b) of the VCLT, has been invoked. The 1970 Working Party Report on Border Tax Adjustments, established by the Council of Ministers in 1968, investigates the practice of the contracting parties. The Panel treats the Report as the practice of the contracting parties in the application of the GATT 1947. The Report was adopted by the contracting parties. The Panel remarks that various criteria of likeness have been used by the panels in previous cases and that the Report summarizes them. In fact, the Report informs that the interpretation of the term "like and similar products" that appears sixteen times in the GATT was seriously discussed by the contracting parties, but no improvement of the term has been achieved. The Working Party concludes that problems of interpretation of the term have to be examined on a case - by - case basis and suggests some criteria of likeness. The Panel notes that these criteria are applied in the 1987 Japan Alcohol case where the panel interprets the terms "like products" in Article III:2, first sentence. ${ }^{42}$ Accordingly, the Panel employs the ordinary meaning method, case law and the Working Party Report, qualified by the Panel as the subsequent practice of the contracting parties in the application of the GATT 1947, to clarify the meaning of the term "like" in Article III:4. Thus, the Panel arrives at conclusion that the same criteria are applicable to the establishment of likeness in both paragraphs of Article III. ${ }^{43}$

Later, another interpretation has been developed. ${ }^{44}$ A particularly exhaustive different interpretation is made in EC-Asbestos by the Appellate Body. ${ }^{45}$ The dictionary is used for establishing ordinary meaning. ${ }^{46}$ The three authentic linguistic versions - the English, French and Spanish - are compared ${ }^{47}$ The Appellate Body has already observed shortages of dictionary meanings ${ }^{48}$ and it repeats the observation. ${ }^{49}$

${ }^{40}$ Panel Report, US - Gasoline, para. 6.7.

${ }^{41}$ Ibid., para. 6.8 .

${ }^{42}$ Ibid.

43 Ibid.

${ }^{44}$ Panel Report, Japan - Alcoholic Beverages II, para. 6.20. Panel Report, Thailand - Customs and Fiscal Measures on Cigarettes from the Philippines, WT/DS371/R, 15 November 2010 (Thailand-Cigarettes (Philippines),para. 7.662.

${ }^{45}$ Appellate Body Report, EC-Asbestos, paras. 89-99.

${ }^{46}$ Ibid., para. 90.

${ }^{47} \mathrm{Ibid}$, para. 91.

48 Appellate Body Report, Canada - Measures Affecting the Export of Civilian Aircraft, WT/DS70/AB/R, adopted 20 August 1999, para. 153.

${ }^{49}$ Appellate Body Report, EC-Asbestos, para. 92. 
The context of Article III:4 and the relationship between the first and second paragraphs in Article III are distinguished as especially relevant. ${ }^{50}$ Article III:2 relates to fiscal regulation and covers two groups of products: "like products" in the first sentence, and "directly competitive or substitutable products," in the second sentence. Article III:4 governs non-fiscal measures and refers only to "like products." This difference in respect of range of products will be of key importance in the interpretation.

Having in view that the same term is used in the same Article, the Appellate Body recognizes that it might have the same meaning in both paragraphs. However, the Appellate Body reminds that the paragraphs of Article III, including the second and the fourth paragraph have been seen in a previous case as an expression of the general principle of national treatment as it is stated in the first paragraph. Thus, 'the 'general principle' set forth in Article III:1 'informs' the rest of Article III and acts 'as a guide to understanding and interpreting the specific obligations contained' in the other paragraphs of Article III, including paragraph 4". ${ }^{51}$ The Appellate Body informs, also, about the purpose of Article III, which has been already defined in a previous case as equal competitive conditions for imported and domestic products. That implies equal protection of imported products in respect to fiscal and non-fiscal measures. Thus, the "particular contextual significance" of Article III:1 in interpretation of Article III:4 is manifesting in the logical expectation of an equal scope of application of the general principle in the second and the fourth paragraph, it is in an equal scope of products subject to fiscal and non-fiscal measures in the two paragraphs. Accordingly, the meaning of "like products" in Article III:4 includes the meaning of "like products" in the first sentence of Article III:2 and the meaning of "directly competitive or substitutable products" in the second sentence of Article III:2. ${ }^{52}$ Consequently, the scale of criteria of like products in Article III:4 is broader than that concerning only Article III:2, first sentence. Thus, the interpretation, given in US - Gasoline, according to which the same criteria are applicable to likeness of products in paragraphs two and four is not a complete one.

A different outcome of two interpretations of the term "like" in Article III:4 is the consequence of the application of different means. The Panel in US - Gasoline did not consider the issue in the context. It looked at the ordinary meaning, but beyond the context of the provision. The Appellate Body in later cases put "particular contextual significance" of Article III:1 in interpretation of Article III:4. It resulted in a different interpretation.

It is not easy to see what factors in the two cases - US - Gasoline and EC - Asbestos - determined the choice of different means of interpretation. It might

\footnotetext{
${ }^{50}$ Ibid., para. 93.

51 Ibid.

52 Ibid., paras. 98-99.
} 
be the facts of the cases. In US - Gasoline imported and domestic gasoline were like products also in the sense of the narrow criteria of Article III:2, first sentence. In $E C-A$ sbestos it was not so clear that asbestos panels and non-asbestos panels are like products. Paradoxically enough, the Panel in EC-Asbestos, applying the narrow meaning of "like products," finds that asbestos and non-asbestos panels are like products. While applying a broader meaning of like products, the Appellate Body concludes that they are not like products. According to the Appellate Body, the Panel errs concerning the mode of examination of the criteria of likeness of the products. One of the criteria of likeness - "physical properties" - is not investigated separately, but together with other criteria. ${ }^{53}$ Also, the Panel is wrong in excluding the health risk from the examination of the physical properties of the product. ${ }^{54}$ However, for correction of these mistakes, it has not been necessary to broaden the meaning of "like products" in Article III:4. The new interpretation might be provoked by the argument of the European Communities that "under Article III:4, products should not be regarded as 'like' unless the regulatory distinction drawn between them 'entails [a] shift in the competitive opportunities' in favour of domestic products." "The competitive opportunities" are connected with Article III:2, second sentence. Another Appellate Body might reply that it will not consider the argument since, having in view mistakes of the Panel concerning the mode of application of the criteria of likeness and concerning relevance of the health risk, the argument is not relevant for decision. Probably, Article 3 (2) of the Understanding on Rules and Procedures excludes such a reply because a clarification of the provisions is indicated as the purpose of the dispute settlement system. The task of the Appellate Body is not just to resolve a dispute, but it is also to clarify a provision.

\subsection{The significance attributed to various means of interpretation regarding an interpretation of the clause "directly competitive and substitutable products"}

An illustration of importance of the weight which is attributed to means of interpretation for the outcome of interpretation may be found in an interpretation of the words "directly competitive and substitutable products," originated in the second paragraph of Note $A d$ Article III and transplanted in the second sentence of Article III:2. The second sentence of Article III:2 extends the anti-discriminatory effect of the first sentence by its content and by the range of products. It states that "no contracting party shall otherwise apply internal taxes or other internal charges to imported or domestic products in a manner contrary to the principles

\footnotetext{
${ }^{53}$ Appellate Body Report, EC-Asbestos, para. 111.

${ }^{54}$ Ibid., para. 116.

${ }^{55}$ Ibid., para. 86.
} 
set forth in paragraph 1". Paragraph 2 of Note Ad Article III qualifies the relationship between imported and domestic products by explaining that the second sentence of Article III:2 has to be applied to cases "where competition was involved between, on the one hand, the taxed product and, on the other hand, a directly competitive or substitutable product which was not similarly taxed". The words "directly competitive or substitutable product" are interpreted in the Japan - Alcoholic Beverages II case and in the Korea-Alcoholic Beverages case. Almost the same means are applied, but the results are different.

The Panel in Japan - Alcoholic Beverages II applies the principle of "effective treaty interpretation" 56 to make distinction between "like" and "directly competitive and substitutable products." It considers the disputed words in the context, that is in connection with other text found in Note Ad Article III ${ }^{57}$ and the Panel refers to the ordinary meaning of the terms "directly competitive and substitutable products". ${ }^{58}$ In the same case, the Appellate Body considered the issue in the light of the object of the GATT 1994, that is in light of the fact that the GATT 1994 is a commercial agreement and the WTO is oriented to markets. ${ }^{59}$ Applying these methods they established that the decisive criterion whether "two products are directly competitive or substitutable is whether they have common end-uses, inter alia, as shown by elasticity of substitution" 60 and, in connection with that, the responsiveness of consumers to various products offered at the market. ${ }^{61}$

In Korea - Alcoholic Beverages the Appellate Body employs the ordinary meaning of the terms, the context, the object and purpose, case law and grammatical analysis to interpret the same words "directly competitive or substitutable". ${ }^{62}$ The context is used as a legal context and as a factual context ("the context of the competitive relationship is necessary marketplace..." $)^{63}$ The grammatical method was engaged for rejecting the grammatical argument of Korea. The wording of the phrase implies, according to the Appellate Body, "that the competitive relationship between products is not to be analyzed exclusively by reference to current consumer preferences. ${ }^{64}$ The Appellate Body states that "the word 'substitutable' indicates that the requisite relationship may exist between products that are not, at a given moment, considered by consumers to be substitutes but which are, nonetheless, capable of being substituted for one another." ${ }^{\text {(65 }}$

\footnotetext{
${ }^{56}$ Panel Report, Japan - Alcoholic Beverages II, para. 6.22.

${ }^{57}$ Ibid.

${ }^{58}$ Ibid., 6.28 .

${ }^{59}$ Appellate Body Report, Japan - Alcoholic Beverages II, p. 25.

${ }^{60}$ Panel Report, Japan - Alcoholic Beverages II, para. 6.22.

${ }^{61}$ Ibid., para. 6.28.

${ }^{62}$ Appellate Body Report, Korea-Alcoholic Beverages, paras. 114, 117 - 120.

${ }^{63}$ Ibid., para. 114.

${ }^{64}$ Ibid.

${ }^{65}$ Ibid.
} 
Thus, the interpretation in Korea - Alcoholic Beverages goes beyond the existing circumstances of a particular market. The difference is caused by the fact that the Appellate Body attributes decisive weight to the ordinary meaning in Korea - Alcoholic Beverages and in particular to the ordinary meaning of the word "substitutable". In Japan - Alcoholic Beverages II the focus is on the context of the provision, it is on the text of Note $A d$ Article III that refers to the market's circumstances. The Panel indeed mentions the ordinary meaning but did not establish the ordinary meaning of the disputed words. It was primarily guided by the words of the context "where competition exists" and concluded that "competition exists by definition on markets." 66

The second interpretation is the reply of the Appellate Body to the argument of Korea that the Panel pursues "an unacceptably broad and speculative approach to the role of potential competition" contrary to the wording, context and object and purpose of Article III:2, second sentence. ${ }^{67}$ The Appellate Body finds that the argument is not sustainable. The Panel in Korea - Alcoholic Beverages did not base its decision on potential competition but on present direct competition. ${ }^{68}$ It was enough to rebut the argument, but the Appellate Body has clarified the meaning of the clause.

\subsection{Breadth of meaning can be shaped by the combination of means of interpretation}

The acceptance of strict, literal meaning or broader meaning can depend on the combination of various means of interpretation. It is visible in the two following cases. In US - Gasoline the Panel finds that the concept of stability and certainty requires the acceptance of a strict, literal interpretation. Since the wording of Article III:4 imposes a comparison of the treatment of imported and domestic products, the Panel rejects a broader interpretation according to which the Article includes also a comparison of effects of the treatment to foreign and domestic producers. The Panel gives two arguments. The broader interpretation is contrary to the ordinary meaning of terms of Article III:4. And second, the broader interpretation would induce instability and uncertainty and that would be inconsistent with the object and purpose of Article III. ${ }^{69}$ The Panel combines the concept of stability and certainty with the object and purpose of the Article and arrives at a strict literal interpretation.

Applying the principle of effectiveness in Brazil-Taxation, the Panel comes to the opposite outcome. It sees the language of Article III, including paragraph 4 , as a broad and inclusive language which does not exclude a possibility that a

\footnotetext{
${ }^{66}$ Panel Report, Japan - Alcoholic Beverages II, para. 6.22.

${ }^{67}$ Appellate Body Report, Korea - Alcoholic Beverages, para. 112.

${ }^{68}$ Ibid., para. 113.

${ }^{69}$ Panel Report, US - Gasoline, para. 6.12.
} 
measure directed at a producer rather that a product affects internal sale, as it is foreseen by Article III:4. The Panel states also that the formalistic approach would make the obligation of national treatment ineffective. ${ }^{70}$ Combing characteristics of the text and the principle of effectiveness the Panel creates a broader meaning.

The comparative facts of the two cases might give good reason for the different combinations of means of interpretation and different outcomes. In US Gasoline the Responded Party tried to justify a different treatment of domestic and imported gasoline by differences between domestic refineries and importers in respect to possession of certain data. In Brazil - Taxation the Responded Party claimed that the measure is directed to producers, not to products. However, in both cases domestic and imported products were treated differently and the panels used different means and different interpretations to achieve the same purpose - equal treatment.

\subsection{Judicial activism in interpretation of the terms "like products"}

Missing reliable sources for collecting information needed for replying to key questions of some generic terms, such as "like products," pushes the panels and the Appellate Body to judicial reasoning guided by the principle of good faith to answer the questions. The Panel in US - Gasoline notes that the various criteria of likeness have previously been applied by the panels under GATT 1947. It quotes the 1970 Working Party Report on Border Tax Adjustments, a document adopted by the contracting parties, which suggests certain criteria of likeness to be applied on a case-by-case basis. ${ }^{71}$ Thus, 1970 Working Party Report has consolidated the criteria of likeness as had appeared in previous case law as follows: "the product's end-uses in a given market; consumers' tastes and habits, which change from country to country; the product's properties, nature and quality". The ordinary meaning and the context do not refer to the product's end-uses or to consumers' tastes and habits. The panels were probably looking at the object and purpose of the GAAT and came to the mentioned criteria, guided by the principle of good faith and using a little of creativity.

${ }^{70}$ Panel Report, Brazil - Taxation, para. 7.63.

${ }^{71}$ The quoted part of the 1970 Working Party Report reads:

"With regard to the interpretation of the term 'like or similar products', which occurs some sixteen times throughout the General Agreement, it was recalled that considerable discussion had taken place . . . but that no further improvement of the term had been achieved. The Working Party concluded that problems arising from the interpretation of the terms should be examined on a case-by-case basis. This would allow a fair assessment in each case of the different elements that constitute a 'similar' product. Some criteria were suggested for determining, on a case-by-case basis, whether a product is 'similar': the product's end-uses in a given market; consumers' tastes and habits, which change from country to country; the product's properties, nature and quality." Panel Report, US - Gasoline, para. 6.8. 
The panels and the Appellate Body under the GATT 1994 have continued to apply criteria that are indicated in the Working Party Report. ${ }^{72}$ It is a unique example of interpretative interaction between the contracting parties and the judicial bodies.

\subsection{Correct and incorrect application of means of interpretation}

The care by which means of interpretation are applied is not without importance. The issue became obvious concerning a difference between the Panel and the Appellate Body in determination of relevance of the health risk for assessment of likeness of products under Article III:4. The Panel pursues a textual approach and applies the principle of effectiveness. It elaborates on the principle by observing the importance which the Appellate Body attaches to it and by transmitting essential information about the principle and its integration in Article 31 (1) from the 1966 Yearbook of the International Law Commission. The principle requires interpretation which will enable the treaty to produce the appropriate effects. ${ }^{73}$ The Panel uses two mutually interrelated arguments concerning the principle of effectiveness. According to the first argument the treatment of human health as a criterion of likeness would enable the Member to avoid the standards of Article $\mathrm{XX}$, including the test necessity and the prohibition of discrimination under the chapeau of the Article. ${ }^{74}$ The second argument relates to the (legal normative) economy of the GATT $1994^{75}$ and, in a version of the Appellate Body, as paraphrased by the Panel, "all these provisions in the WTO Agreement must be given meaning". ${ }^{76}$ The Panel considers that the introduction a health risk among criteria of likeness would largely deprive Article XX (b) of the effect. ${ }^{77}$ Also, the Panel notes that Article XX (b) covers the protection of human health and life and that Article III does not refer to this.

The Appellate Body uses terms effet utile which express one version of the principle of effectiveness, used by the Panel, and argues that the recognition of the health risk as a criterion of likeness under Article III:4 does not deprive Article XX (b) of effet utile. ${ }^{78}$ The two Articles are, the Appellate Body remarks, separate and independent provisions of the GATT 1994 and each has to be inter-

\footnotetext{
${ }^{72}$ Panel Report, EC-Asbestos, para. 8.131 and 8.132. Appellate Body Report, EC-Asbestos, para. 101.

73 Panel Report, European Communities - Measures Affecting Asbestos and AsbestosContaining Asbestos Products Asbestos, WT/DS135/R, 18 September 2000, (EC-Asbestos), para. 8. 29, f. 22.

${ }^{74}$ Ibid., para. 8.130

${ }^{75} \mathrm{Ibid}$., paras. 8.129, 8.132.

${ }^{76}$ Ibid., para. 8.130.

${ }^{77}$ Ibid., para. 8.130.

${ }^{78}$ Appellate Body Report, EC-Asbestos, para 115.
} 
preted on its own. The Appellate Body reminds us that Article XX (b) allows a Member to "adopt and enforce" a measure necessary to protect life and health. Consequently, the Appellate Body observes that the health risk as a criterion of likeness would deprive Article XX (b) of effet utile only if it would prevent a Member from adopting and enforcing a measure to achieve the objective. ${ }^{79}$ It really does appear to be the case that the health risk as a criterion of likeness under Article III:4 does not deprive Article XX (b) of its effect. Thus, the interpretative argument of the Panel is not sustainable.

\subsection{Assessment of facts and interpretation}

An assessment of facts and an interpretation can be closely connected. The issue of relevance of facts in the application of a provision is the issue of interpretation of the provision. Thus, contrary to the opinion of the Panel, the Appellate Body in $E C$ - Asbestos finds that the health risk is a physical property relevant for establishing likeness of the products. ${ }^{80}$ The Panel in Indonesia - Chicken Meat follows that finding. ${ }^{81}$

It is a well established practice of the panels and the Appellate Body that they decide the issues of "likeness," "directly competitive or substitutable products" or of the relationship between obligations under substantive provisions of the GATT 1994 and the exceptions under Article XX on a case-by-case basis "by careful scrutiny of the factual and legal context in a given dispute." 82 The facts can require an adequate combination of means of interpretation that will give a reasonable outcome, as it has been indicated in the above text.

The overlap of factual finding and interpretation manifests, for example, in reply to the question whether sea turtles constitute an exhaustive natural resource. The issue will be considered later in this text.

\subsection{Interpretative explanations}

Interpretative explanations make the process of interpretation transparent. The panels and the Appellate Body explain the role, the contribution and significance of each applied means of interpretation in some case, but they just invoke means of interpretation in other cases without any explanation. The issue is touched on in Article 12 (7) of the Understanding on Rules and Procedures which requires, inter alia, that the report of a panel includes the findings of fact, the findings of

\footnotetext{
${ }^{79}$ Ibid.

${ }^{80}$ Ibid., para. 116.

${ }^{81}$ Panel Report, Indonesia - Measures concerning the Importation of Chicken Meat and Chicken Products, WT/DS484/R, 17 October 2017, (Indonesia-Chicken Meat), paras 7.315 - 7.317.

${ }^{82}$ Appellate Body Reports, US - Gasoline, p. 18., EC-Asbestos, para. 101.
} 
law and "the basic rationale behind any findings and recommendations that it makes." Having in view the ordinary meaning of the terms "basic rational," as defined by a dictionary, the Appellate Body in Korea - Alcoholic Beverages interprets the terms to mean "the minimal nature of explanation". ${ }^{83}$ However, such minimal explanation has to ensure the Members understand the manner in which the panel has applied the provision and to enable the Appellate Body to exercise its review. ${ }^{84}$ The manner in which the panel applies the provision is very much connected with interpretation. A proper explanation proportional to the importance of the issue contributes to the rightfulness of interpretation.

\section{MEANS AND MODES OF INTERPRETATION OF ARTICLE XX}

\subsection{Textual interpretation as the basic approach}

Article XX of GATT 1994, under the title "General exceptions" consists of the general requirement on the prohibition of arbitrary and unjustifiable arbitration and disguised restriction on international trade, formulated in the "chapeau" and of specific exceptions in paragraphs (a) to (j). Paragraphs on the specific exceptions determine the objectives of exceptions, such as the protection of public morals, life or health or exhaustible natural resources and the relationships between a measure taken to achieve an objective, and that objective. An interpretative note is attached to paragraph (h), but it is of small importance for interpretation.

The Appellate Body has declared that the basic principle of interpretation of Article XX is the utilization of the ordinary meaning of the terms, in their context and in light of the object and purpose of the treaty. ${ }^{85}$ It is interesting that the Appellate Body in US-Gasoline quotes Article 31 (1) of the VCLT and then paraphrases its content in three different ways. That interpretative exercise might indicate essence of the Appellate Body's approach to interpretation. The first version reads: "Applying the basic principle of interpretation that the words of a treaty, like the General Agreement, are to be given their ordinary meaning, in their context and in the light of the treaty's object and purpose..." 86 The formulation is given in the context of the observation of the Appellate Body that the Panel failed to consider "the words actually used by Article XX in its several paragraphs." 87

${ }^{83}$ Appellate Body Report, Korea - Alcoholic Beverages, para. 90.

${ }^{84}$ Ibid., para. 91.

${ }^{85}$ Appellate Body Report, US - Gasoline, pp. 17, 21. Appellate Body Report, United States - Import Prohibition of Certain Shrimps and Shrimps Products, WT/DS58/AB/R, 12 October 1998, (US - Shrimp), para. 155.

${ }^{86}$ Appellate Body Report, US -Gasoline, p. 18.

${ }^{87}$ Ibid. 
The following version - "Article XX (g) and its phrase, 'relating to the conservation of exhaustible natural resources,' need to be read in context and in such a manner as to give effect to the purposes and objects of the General Agreement" - appears on the same page as an interpretative justification for reading the quoted phrase in context of Articles I, III and IX and in particular in the context of the purpose and object of Article III:4. ${ }^{88}$ Article 31 (1) of the VCLT uses the object and purpose of a treaty in singular. The Appellate Body refers to the object and purpose of paragraph 4 of Article III and probably considers that Articles and even paragraphs can have their specific objects and purposes. Having that in view, the Appellate Body reformulates the text of Article 31 (1) of the VCLT replacing singular by plural in respect to the object and purpose of a treaty. Later, the panels and the Appellate Body will formulate a purpose of Article III, or of the general principle in Article III:1, or of the introductory sentence (the chapeau) of Article XX and use such a formulated purpose in interpretation of the rest of the Articles.

Having passed to interpretation of the next clause in Article XX (g) - "if such measures are made effective in conjunction with restrictions on domestic production or consumption" - the Appellate Body states "that the basic international law rule of treaty interpretation, discussed earlier, that the terms of a treaty are to be given their ordinary meaning, in context, so as to effectuate its object and purpose, is applicable here, too." 89 The Appellate Body establishes the ordinary meaning of the terms by reliance on the dictionary, then refers to the context of Article III:4 and uses arguments related to legal certainty to clarify the clause. The remark that "the basic international rule of treaty interpretation ... is applicable here, too" might indicate an understanding that the rule is not applicable everywhere but only on appropriate occasions. It also quite obvious that the Appellate Body has fine tuned the basic rule of interpretation according to its interpretative needs. It might indicate further that the Appellate Body forms pre-interpretative understanding of the issue and that it adjusts the interpretation to that understanding. However, these implications which can be derived from the presented interpretative exercise are not necessarily reliable. An empirical review confirms that the methods which constitute the textual approach are used regularly. However, there is no full consistency in their usage.

The following methods are used in the broader framework of the textual approach: the ordinary meaning method, usually with reliance on dictionaries, ${ }^{90}$

${ }^{88}$ Ibid.

${ }^{89}$ Ibid., p. 21.

${ }^{90}$ Appellate Body Report, India - Certain Measures Relating to Solar Cells and Solar Modules, WT/DS456/AB/R, 16 September 2016 (India - Solar Cells), para. 5.106. Appellate Body Report, US - Gasoline, p. 20. Appellate Body Reports, China - Measures Related to the Exportation of Various Raw Materials, WT/DS394, 395, 398/AB/R, 30 January 2012 (China - Raw Materials), para. 325. Appellate Body Report, EC - Seal Products, para. 5.197. 
the context, ${ }^{91}$ the purposes and objects of the GATT $1994,{ }^{92}$ the purpose and object of the introductory clause of Article XX, ${ }^{93}$ principle of reasonableness ${ }^{94}$ and principle of effectiveness. ${ }^{95}$ However, beyond the textual approach a broad scale of sources and methods are employed: case law, the relevant rules of international law applicable between the parties,${ }^{96}$ drafting history of Article XX, ${ }^{97}$ scientific sources, ${ }^{98}$ evolutionary interpretation, ${ }^{99}$ the case law of the International Court of Justice and textbooks of international law. Case law is used very frequently. The other sources and methods have been employed rather exceptionally.

\subsection{Excursion beyond textual interpretation regarding interpretation of "exhaustible natural resources"}

The broadest scale of means of interpretation is employed to answer the question whether sea turtles fall under "exhaustible natural resources" in Article $\mathrm{XX}(\mathrm{g})$. The principle argument of complainants is that living natural resources are renewable and consequently they cannot be exhaustible natural resources. The Appellate Body employs more sources and methods to answer to the argument, including the biological sciences, the relevant rules of international law applicable between the parties, the evolutionary interpretation, the case law of the International Court of Justice and literature of international law, the preamble of the WTO Agreement, the cases of the panels and the principle of effectiveness.

The biological sciences confirm that living species can be exhaustible and can become extinct due to human activities. ${ }^{100}$ The contemporary concerns of the community of nations, according to the Appellate Body, informs the phrase "exhaustible natural resources," which was formulated fifty years ago. ${ }^{101}$ The Appellate Body enumerates international conventions and other international acts by which the international community has expressed the concerns regarding the preservation of the environment ${ }^{102}$ and finds that the international community

${ }^{91}$ Appellate Body Reports, EC - Seal Products, paras. 5.197, 5.198., US - Gasoline, p. 18. Appellate Body Report, US - Shrimp, para. 155.

${ }^{92}$ Appellate Body Report, US - Gasoline, p. 18.

${ }^{93}$ Ibid., p. 22

${ }^{94}$ Ibid., p. 18.

${ }^{95}$ Appellate Body Report, US - Shrimp, paras. 121, 131.

${ }^{96}$ Appellate Body Report, China - Measures Related to the Exportation of Rare Earths, Tungsten, and Molybdenum, WT/DS431, 432,433/AB/R, 7 August 2014, (China-Rare Earths), para. 5.55. Appellate Body Report, US - Shrimp, para. 131.

${ }^{97}$ Appellate Body Report, US - Gasoline, p. 22.

${ }^{98}$ Ibid., 128, 133.

${ }^{99}$ Ibid., paras. 129, 130.

${ }^{100}$ Appellate Body Report, US - Shrimp, para. 128.

${ }^{101}$ Ibid., para. 129.

${ }^{102}$ Ibid., para. 130. 
acknowledges the importance of multilateral and bilateral actions for the protection of living natural sources. ${ }^{103}$ It finds that the term "natural resources" is a "generic term" and as such its meaning is not static but evolutionary. ${ }^{104}$ Case law of the International Court of Justice ${ }^{105}$ and the international law literature ${ }^{106}$ is used for the elaboration of an evolutionary interpretation. The Appellate Body observes that the preamble of the WTO Agreement invokes the objective of sustainable development, the concept that should provide mutual supportiveness between international trade and the preservation of the environment. ${ }^{107}$ Thus, the WTO Members accept sustainable development as the objective in the preamble of the WTO Agreement. ${ }^{108}$ Two reports of the panels under the GATT 1947 found that fish were an exhaustible natural resources. ${ }^{109}$ It is in line with the principle of effectiveness that all exhaustible resources, living and non-living, can fall under Article XX (g). ${ }^{110}$ Having these information in view, the Appellate Body comes to the following interpretation: "it is too late in the day to suppose that Article $\mathrm{XX}(\mathrm{g})$ of the GATT 1994 may be read as referring only to the conservation of exhaustible mineral or other non-living natural resources." 111

It was not for the first time that living natural resources have been subsumed under exhaustible natural resources, but the interpretative approach was quite new. It has gone far away beyond Article 31 (1) of the VCLT. The sources, which do not necessarily express intention or understanding of the contracting parties, such as biological sciences or concerns of international community expressed in international documents have been consulted.

\subsection{A return to a textual approach in interpretation of the chapeau of Article XX}

After the departure from the textual approach, the Appellate Body returns to it in interpretation of the chapeau of Article $\mathrm{XX}$ in connection with paragraph (g). It is significant that the Appellate Body is not ready to interpret in the same manner the text of the paragraphs of Article XX and the chapeau of Article XX.

\section{Ibid.}

${ }^{104}$ Ibid., para. 130.

105 The Appellate Body refers to Namibia (Legal Consequences) Advisory Opinion (1971) I.C.J. Report, p. 31. Aegean Sea Continental Shelf Case, (1978) I.C.J. Report, p. 3.

106 The following texts are mentioned: “Jennings and Watts (eds.), Oppenheim's International Law, 9th ed., Vol. I (Longman's, 1992), p. 1282 and E. Jimenez de Arechaga, "International Law in the Past Third of a Century", (1978-I) 159 Recueil des Cours 1, p. 49”.

${ }^{107}$ Appellate Body Report, US - Shrimp, para. 131.

108 Ibid.

${ }^{109}$ Ibid., para. 131.

110 Ibid.

${ }^{111}$ Ibid. 
The Appellate Body indicates the reason of transition to textual mode of interpretation that might be helpful for an understanding of its interpretative logic. The preamble of the WTO Agreement was the starting point. The Appellate Body observes that "this language (of the preamble) demonstrates recognition by WTO negotiators that optimal use of the world's resources should be made in accordance with the objective of sustainable development." 112 It finds further expression of the intention of the WTO Members in the Decision of Ministers at Marrakesh to establish a permanent Committee on Trade and Environment, the substance of which is the understanding that harmony between an open and equitable multilateral trading system and the protection of the environment is possible and needed and it is expressed as a sustainable development. ${ }^{113}$ The Decision established the terms of reference for the Committee on Trade and Environment. Having remarked that the General Council of the WTO established the Committee in 1995 and that the Committee has begun its work, the Appellate Body observes:

"Pending any specific recommendations by the CTE to WTO Members on the issues raised in its terms of reference, and in the absence up to now of any agreed amendments or modifications to the substantive provisions of the GATT 1994 and the WTO Agreement generally, we must fulfill our responsibility in this specific case, which is to interpret the existing language of the chapeau of Article $\mathrm{XX}$ by examining its ordinary meaning, in light of its context and object and purpose in order to determine whether the United States measure at issue qualifies for justification under Article XX..."114

The words "in the absence up to now of any agreed amendments or modifications to the substantive provisions of the GATT 1994 and the WTO Agreement generally, we must fulfill our responsibility in this specific case, which is to interpret the existing language of the chapeau" are of very much significance. They disclose the conviction of the Appellate Body that the preamble of the WTO Agreement and an announcement of the Members of their intention to advance sustainable development, but without agreed amendments or modifications of the substantive provisions of the GATT 1994, are not in themselves enough to produce the decisive effect in interpretation of the chapeau of Article XX. Thus, it seems that the Appellate Body makes a distinction between an interpretative mode suitable for interpretation of paragraphs of Article XX and an interpretative mode proper for an interpretation of the chapeau. The first is not limited exclusively to expressions of intention of the contracting parties. The second mode is limited. The difference in approaches might be explained by the different nature of objects of the provisions. The objects of the paragraphs - protection of public morals, life,

\footnotetext{
112 Ibid., para. 153.

${ }^{113}$ Ibid., para. 154.

${ }^{114}$ Ibid., para. 155.
} 
health or natural resources - do not belong only to international trade law, but also to other branches of international law. On the other hand, the content of the chapeau - prohibition of discrimination and disguised restriction on international trade is the essence of international trade law. It might be presumed that the nature of international trade law and nature of international environmental law or of international human rights law dictated different interpretative approaches. Later in the text, an analysis of interpretation of the chapeau in this case will be presented.

\subsection{Other departures from textual approach and the problem of over-interpretation}

Certain other departures from the textual approach of the panels of the Appellate Body, which requires holding fast to the terms used in a provision, have been developed in case law. In Indonesia - Chicken Meat the Panel formulates two basic requirements of Article XX (d) "in line with relevant guidance provided by the Appellate Body" in previous cases. ${ }^{115}$ These are qualifications of disputed measures as "designed to" achieve an objective and as "necessary" for the achievement of an objective. The text of the provision requires that a measure is "necessary to secure compliance with laws or regulations..." The term "designed" is not used. The previous interpretation of the requirement "designed" by the Appellate Body ${ }^{116}$ informs that the requirement is met when examination of the design of a measure confirms that the measure is not incapable of securing compliance with relevant laws and regulations. ${ }^{117}$

The path of development of the requirement "designed" can be traced back to an observation of the Appellate Body in US - Gasoline. Resolving a disagreement between the parties, whether the Respondent Party has to show that the disputed measure has already produced some positive conservative effect, the Appellate Body in US - Gasoline interprets the second clause of Article XX (g) which reads: "if made effective in conjunction with restrictions on domestic production or consumption." 118 The Appellate Body applies a few means of interpretation and employs also practical arguments concerning legal certainty to refute the assertion that the clause implies the test of effectiveness. The effect of a measure for the conservation of natural resources is not immediately detectable and

115 Appellate Body Report, Korea - Various Measures on Beef, para. 157. Appellate Body Report, Argentina - Measures Relating to Trade in Goods and Services, WT/DS453/AB/R, 14 April 2016, (Argentina - Financial Services), para. 6.202; and Colombia-Textiles, para. 5.123. Panel Report, Indonesia - Chicken Meat, para. 7.411.

116 Appellate Body Report, Columbia - Measures Relating to the Importation of Textiles, Apparel and Footwear, WT/DS461/AB/R, 7 June 2016, (Colombia - Textiles), para. 5.68.

117 Panel Report, Indonesia - Chicken Meat, para. 7.415.

118 Appellate Body Report, US - Gasoline, p. 21. 
the causality between a measure and conservation is not easy to prove. ${ }^{119}$ However, the Appellate Body remarks that that does not mean that the issue of effect of measures is never relevant. If a measure cannot have any positive effect on the conservation of natural resources, "it would very probably be because that measure was not designed as a conservation regulation". 120 This remark has become the starting point of the development of the requirement "designed" in case law.

The observation that a measure has to be designed to achieve an objective was born in interpretation of Article XX (g) that relates to the protection of exhaustible natural resources and through case law transferred to paragraphs (a), (b) and (d) of Article XX relating to public morals, ${ }^{121}$ life and health and to compliance with laws or regulations. ${ }^{122}$ In US - Gasoline, where the developments in case law begins, the Appellate Body uses the word "designed" as a synonym of the words "primarily aimed at". ${ }^{123}$ The words "primarily aimed at" are construction of the term "relating to". The Panel in US - Gasoline states that the term "relating to" in Article XX (g) does not mean "necessary" or "essential", but "primarily aimed at". ${ }^{24}$ Thus, the word used in connection with interpretation of the term "relating to" has become employed in interpretation of the term "necessary". Obviously, the terms "relating to" and "necessary" have not the same meaning as the Appellate Body has already established that. ${ }^{125}$

Having in view that one of the criteria of "necessity" requirement is the contribution of a measure to the achievement of an objective and the criterion of the requirement "designed" is that a measure is not incapable of achieving an objective, it might be asked whether the requirement of "designed" measure is consumed by the requirement of "necessity"? In other words, it might be said that the criterion of the contribution of a measure to the achievement of an objective preempts the criterion of capability of achieving an objective. Whether it is imaginable that a measure does indeed contribute to the accomplishment of an objective, but then that it is not capable of doing that? If such a situation were imaginable, the answer would be that a measure does not satisfy the requirement of paragraphs (a), (b) and (d) of Article XX. ${ }^{126}$ The answer would be contrary to the text of the paragraphs, since the text does not use term "designed," but only the term "necessary". On the other hand, in the case of finding that a measure is not incapable of achieving an objective, investigation of its contribution to the achievement of

119 Ibid., p. 22.

${ }^{120}$ Ibid.

${ }^{121}$ Appellate Body Report, Colombia - Textiles, para. 5.68.

122 Appellate Body Report, Korea - Various Measures on Beef, para. 157.

${ }^{123}$ Appellate Body Report, US - Gasoline, p. 22.

${ }^{124}$ Canada - Measures Affecting Exports of Unprocessed Herring and Salmon, BISD 35S/98, para 4.6 (adopted on 22 March 1988). Panel Report, US - Gasoline, para. 6.39. f. 40.

${ }^{125}$ Appellate Body Report, US - Gasoline, p. 18.

${ }^{126}$ Appellate Body Report, Columbia - Textile, para. 5.68. 
an objective follows. It might be that the requirement "designed" is a deadlock in case law in the development of interpretation of paragraphs (a), (b), and (d) of Article XX, which might be a consequence of over-interpretation.

A signal of a possible uncertainty concerning the issue might be found in Columbia - Textile. The Panel finds that Columbia failed to demonstrate that a measure is designed to protect public morals under Article XX (a) and, consequently, that there is no need to examine whether the measure is necessary to protect public morals. ${ }^{127}$ "However, in order to be exhaustive in its analysis," the Panel investigates whether the measure has been necessary to protect public morals and finds again that Columbia has not demonstrated that the measure is necessary. ${ }^{128}$ It might be asked what really was the motive that the Panel explored the necessity requirement: stemming an exhaustive analysis or an uncertainty about the completeness of the reply to requirement of Article XX (a) without addressing the "necessity" requirement?

\subsection{The nature of the objective of a provision and interpretation}

The issue has been touched above in discussion of different interpretative approaches regarding the provisions of paragraphs and the chapeau of Article XX. The issue appears here in a similar context. The nature of the objective, which is protected by a paragraph of Article XX, can influence the meaning of a linked term. The Appellate Body in EC - Seal Products considers the meaning of the term "to protect" in paragraphs (a) and (b) and finds that the context gives to the same term different meanings just because the protection of the objective under paragraph (a) - public morals - cannot be ascertained in the same way as the protection of the objective under paragraph (b) - human, animal or plant life or health. An exploration as to whether a measure protects life or health includes an investigation of the existence of a risk to life or health and consultation of scientific sources. Ascertaining whether a measure protects public morals is examined by other means. ${ }^{129}$

\subsection{An odd resolution of the conflict between information originating in the preparatory work and in the text in interpretation of the clause "arbitrary or unjustifiable discrimination"}

The clause which is laid down in the chapeau of Article XX and reads: "Subject to the requirement that such measures are not applied in a manner which would constitute a means of arbitrary or unjustifiable discrimination between

\footnotetext{
${ }^{127}$ Panel Report, Columbia - Textile, para. 7.402.

${ }^{128}$ Ibid., para. 7.470.

${ }^{129}$ Appellate Body Report, EC - Seal Products, para. 5.198.
} 
countries where the same conditions prevail, or a disguised restriction on international trade" is interpreted by different means in different cases. In the US Gasoline, the Appellate Body applies the principle l'effet utile, the context and the purpose and object of the chapeau. The name of the principle "l'effet utile" is not used, but the Appellate Body expresses its content by stating that "interpretation must give meaning and effect to all the terms of a treaty"130 The absence of reference to the ordinary meaning method is remarkable. The principle l'effet utile is qualified as one of the consequences of the general rule on interpretation in the VCLT and some decisions of the International Court of Justice, the 1996 Yearbook of International Law Commission and some textbooks of international law are invoked as evidence of the existence of the principle. ${ }^{131}$ The contextual aspect is present in the understanding of the Appellate Body that the phrases "impart meaning to one another." 132 The significance of the purpose and the object of chapeau is emphasized by the remark that "the fundamental theme is to be found in the purpose and object of avoiding abuse or illegitimate use of the exceptions..."133 It seems that negotiating history extended the most important information about the purpose of the chapeau. The following statement of the Appellate Body comes from the preparatory work: "If those exceptions are not to be abused or misused, in other words, the measures falling within the particular exceptions must be applied reasonably, with due regard both to the legal duties of the party claiming the exception and the legal rights of the other parties concerned." 134

In US - Shrimps the Appellate Body begins by remarking that the text of the chapeau will be interpreted by an examination of its ordinary meaning in light of the context, object and purpose. ${ }^{135}$ In fact, it engages the principle of good faith, the doctrine of abus de droit, plain language and negotiating history. All means have been employed to clarify the relationship between the substantive provisions of the GATT 1994 and paragraphs (a) to (j) of Article XX. By referring to Article 32 of the VCLT, as a legal basis for application of the preparatory work, and by extracting relevant points from the negotiating history, the Appellate Body observes that the preparatory work confirms the clear meaning of the text. ${ }^{136}$ It finds further that the chapeau expresses the principle of good faith, "at once a general principle of law and a general principle of international law". ${ }^{137}$ The principle forbids the abuse of right and requires bona fide and reasonable exercise of rights.

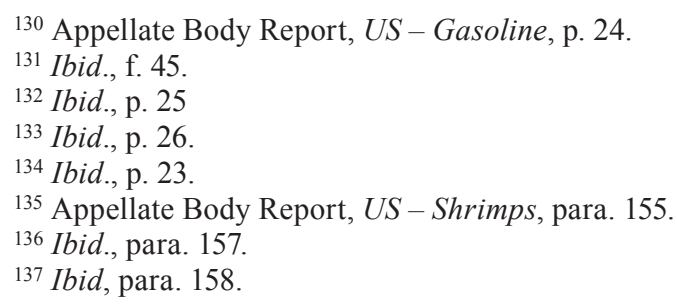


The Appellate Body refers to Article 31 (3) (c) as a legal basis of applying the principle. Also, it invokes international law literature and jurisprudence of the International Court of Justice as evidence of the existence and content of the principle. The essence of interpreting and applying the chapeau is "locating and marking out a line of equilibrium between the right of a Member to invoke an exception under Article XX and the rights of the other Members under varying substantive provisions". ${ }^{138}$ In spite of the fact that the Appellate Body used the preparatory work only to confirm the meaning obtained by another means, information of key importance has been derived just from the preparatory work. The first draft of the chapeau did not contain references to discrimination and disguised restriction and they were inserted to prevent an abuse of the exceptions. ${ }^{139}$

Having been a result of dominance of the same means of interpretation - the preparatory work, outcomes of interpretations in US - Gasoline and US - Shrimps are maybe not identical but there are not significant discrepancies between them. If one looks at the way the chapeau is applied in the two cases, further similarities are detectable. The manner of the application of the chapeau in the two cases discloses that the Appellate Body connects the prohibited forms of discrimination with different treatments. In US-Gasoline, it remarks that the absence of a difference in treatment of imported and domestic products means the absence of discrimination. ${ }^{140}$ In US - Shrimps the Appellate Body states that differences in treatment of different countries constitute unjustifiable discrimination. ${ }^{141}$ In both cases different treatment does not exhaust the whole content of prohibited forms of discrimination. In US - Gasoline, the existence of an alternative measure is of importance. ${ }^{142}$ The same is of importance, also, in US - Shrimps, but there "rigidity and inflexibility" in the application of the measure and absence of basic fairness and due process is qualified as arbitrary discrimination. ${ }^{143}$

The two cases have another common feature. There is no clear and natural nexus between interpretation of the clause - "Subject to the requirement that such measures are not applied in a manner which would constitute a means of arbitrary or unjustifiable discrimination between countries where the same conditions prevail, or a disguised restriction on international trade,..." - and its application. One of the key elements of the application is a different treatment and the interpretation clarifies the provision to mean a search of equilibrium between the rights based in exceptions and the rights based in other substantive provisions of the GATT 1994 without mentioning different treatments. In fact, two interpretations are

138 Ibid, para. 159.

${ }^{139} \mathrm{Ibid}$, para. 157

${ }^{140}$ Appellate Body Report, US - Gasoline, pp. 26, 29.

${ }^{141}$ Appellate Body Report, US - Shrimps, para. 176.

${ }^{142}$ Appellate Body Report, US - Gasoline, pp. 26-28.

${ }^{143}$ Appellate Body Report, US - Shrimps, paras. 177, 181. 
present in the two cases: the first, explicated in explanation, which flows from the dominant position of the preparatory work, and the second, implied in the application of the chapeau, which streams from the dominant position of the text.

Obviously, the preparatory work and the text extend disharmonic information. It means that the contracting parties have not consistently expressed their original intention through the text. The original intention that the exemptions under Article XX have to be exercised with reasonable regard to the rights of other parties has been modified in prohibition of discriminatory exercise of the exceptions. It might be that the drafters of the final text of the chapeau thought that the prohibition of abuse of exceptions has been already expressed in the text of the exceptions by definition of legitimate objectives of exceptions and by determination of the relationship between a measure and an objective.

The concept of the abuse of right and the concept of discrimination can be connected but they are not identical or interchangeable concepts. The prohibition of abuse of right looks at the purpose of a right and modes of the achievement of the purpose. It requires that in the exercise of a right a reasonable regard is paid to rights of others. The concept of prohibition of discrimination explores the relationship between the factual situations (same or different situations) and their legal treatments (same or different treatment) as well as justification of non-compatible relationship (different treatments of the same situations or the same treatment of the different situations). Thus, the legitimacy of the purpose and the proportionality between the purpose and means taken for its fulfillment can be common for both concepts. But, the concept of abuse of right is mainly exhausted in these two elements and these two elements are just a part of the overall package of the concept of discrimination. Differences or the sameness of the situations and the legal treatments and compatibility or non-compatibility of the legal treatments and the situations is another part of the package. Consequently, the two concepts are overlapping though just partly.

In US - Shrimps the United States argues that "discrimination between countries where the same conditions prevail' is not 'unjustifiable' where the policy goal of the Article XX exception being applied provides a rationale for the justification." 144 Thus, the Responded Party claims that legitimacy of the purpose can justify the different treatment. According to the Responded Party, it is the way by which the chapeau protects against the abuse of the Article XX exceptions. The Appellate Body rejects the argument explaining that "[T]he legitimacy of the declared policy objective of the measure, and the relationship of that objective with the measure..." must be examined under the provision of an exception, not under the chapeau. ${ }^{145}$

${ }^{144}$ Appellate Body Report, US - Shrimps, para. 148.

145 Ibid, para. 149. 
It seems that the Appellate Body has changed its understanding of the issue. In Brazil - Retreaded Tyres Brazil explains that different treatment in respect to the import of retreaded tyres is caused by the ruling of the MERCOSUR arbitral tribunal. Having in view the explanation as well as the negligible effect of import on the general ban of importation of retreated tyres, the Panel finds that the measure is not discriminatory. ${ }^{146}$ Invoking its finding in US - Gasoline, the Appellate Body begins by reminding that "the function of the chapeau is the prevention of abuse of the exceptions specified in the paragraphs of Article XX" ${ }^{147}$ It repeats its crucial findings in US - Shrimps. Looking at the two cases, the Appellate Body observes that the focus has been on the cause and the rationale of discrimination. ${ }^{148}$ Consequently, in Brazil - Retreaded Tyres the Appellate Body considers that there is an abuse and thus arbitrary and unjustifiable discrimination when a measure "is applied in a discriminatory manner" and "when the reasons given for this discrimination bear no rational connection to the objective falling within the purview of a paragraph of Article XX, or would go against that objective". ${ }^{149}$ The ruling of the MERCOSUR arbitral tribunal is based on the provision of MERCOSOR law that prohibits new trade restrictions. As the Appellate Body finds that the ruling of the MERCOSUR arbitral tribunal bears no relationship to the legitimate object of the measure, the Appellate Body concludes that the different treatment constitutes an arbitrary and unjustifiable discrimination. ${ }^{150}$

Another reading of the US - Gasoline and US - Shrimps cases is quite possible. The essence of the two cases might be defined as to the question of whether the achievement of an objective is possible without different treatment. In both cases it was possible, and the Appellate Body found discrimination. However, in Brazil-Retreaded Tyres it is difficult to see how the achievement of the objective would be possible without different treatment. Brazil had three options: to disregard the ruling of the MERCOSUR arbitral tribunal, to give up on the objective or to make difference among countries regarding the import of retreaded tyres.

\subsection{The principle of reasonableness in interpretation of the term "necessary"}

Concerning interpretation of the term "necessary", the panels and the Appellate Body are using "a holistic weighing and balancing exercise" to establish whether a measure is necessary for achieving an objective. "Weighing and bal-

${ }^{146}$ Appellate Body Report, Brazil - Measures Affecting Imports of Retreaded Tyres, WT/ DS332/AB/R, 3 December 2007, (Brazil-Retreated Tyres), para. 219.

147 Ibid., para. 224.

${ }^{148}$ Ibid., paras. 225, 226.

${ }^{149}$ Ibid., para. 227.

${ }^{150}$ Ibid., para. 228. 
ancing exercise" is born in the contextual interpretation of Article XX that demands resolution of competing claims, based on different provisions such as Article III (2) and (4) and Article XX (a) and (b). The WTO Members have the right under Article III (2) and (4) that their products enjoy national treatment in respect to fiscal and non-fiscal measures. On the other hand, the WTO Members have the right to restrict international trade due to the protection of objectives, enumerated in Article XX (a) to (j). These rights may be in conflict which the panels and the Appellate Body are usually resolving by a "weighing and balancing exercise". The Appellate Body explains "that a necessity analysis involves a process of "weighing and balancing' a series of factors, including the importance of the societal interest or value at stake, the contribution of the measure to the objective it pursues, and the trade restrictiveness of the measure. In most cases, a comparison between the challenged measure and possible alternatives should subsequently be undertaken." 151 The alternatives are measures compatible with substantial provisions of the GATT 1994 or less trade-restrictive measure. ${ }^{152}$ The weighing has to be realized by establishing the relative weight of particular factors, such as the importance of the interests or values at stake, ${ }^{153}$ the size of the contribution of a measure to the achievement of the objective and the amount of restrictive effect on international trade. ${ }^{154} \mathrm{An}$ alternative measure has to be "reasonable available." That means that a Member is capable of undertaking it and that the measure does not "impose undue burden on that Member, such as prohibitive costs or substantial technical difficulties." 155

Reading the text of the paragraphs of Article XX "in context and in such a manner as to give effect to the purposes and objects of the General Agreement"156 has led to the quoted meaning of the term "necessary". The drafting history of the chapeau of Article XX is also used. ${ }^{157}$ However, it might be difficult to find specific information in the context of Article XX, in the purposes and objects in the GATT 1994 or in the drafting history of the chapeau about the weighing and balancing exercise or about alternative measures. The mentioned sources can inform that the rights under Article XX and the rights under substantive Article of the GATT 1994, including Article III, have to be reconciled, but they do not

${ }^{151}$ Appellate Body Reports, Colombia - Textiles, para. 5.70. Korea-Various Measures on Beef, para. 166; Brazil - Retreaded Tyres, para. 182; and EC-Seal Products, para. 5.169. Appellate Body Report, United States - Measures Affecting the Cross-Border Supply of Gambling and Betting Services, WT/DS285/AB/R, 7 April 2005, (US - Gambling), para. 306; Panel Report, Indonesia - Chicken Meat, para. 7.224.

${ }^{152}$ Panel Report, Indonesia - Chicken Meat, para. 7.224.

${ }^{153}$ Panel Report, US - Gambling, paras. 6.489-6.492.

${ }^{154}$ Appellate Body Report, Colombia - Textiles, paras. 5.72, 5.73.

155 Ibid., para. 5.74.

${ }^{156}$ Appellate Body Report, US - Gasoline, p. 18.

${ }^{157}$ Ibid., p. 23. 
inform about a mechanism of reconciliation. The panels and the Appellate Body do not refer to the principle of reasonableness, but having in view interpretative practice of other international bodies, the principle has been a facility for creating the mechanism.

The "weighing and balancing" is not an interpretative method that has appeared only in the interpretation of Article XX of the GATT. It is employed in another legal environment where legitimate interest or legal rights are in conflict. Thus, the European Court of Human Rights uses the concept of fair balance which is similar to weighing and balancing. ${ }^{158}$ The International Court of Justice applies the concept of reasonable regard to interests of others in the context of common or divided recourse, such as the sea or rivers ${ }^{159}$ or in the general context of international negotiation. ${ }^{160}$ Reconciliation of conflicting interests or rights by assessment of objectives and means for their pursuance is connected with the general principle of reasonableness in international law. The International Court of Justice noted that the principle of good faith requires a reasonable application of the law. ${ }^{161}$

\section{CONCLUSIONS}

The panels and the Appellate Body apply Articles 31 and 32 of the VCLT to interpretation of Article III:2 and 4 and Article XX of the GATT 1994. Most frequently they employ the first paragraph of Article 31. Other paragraphs of Article 31 and Article 32 are used exceptionally. The texts of the Articles, the GATT 1994 as a whole and Interpretative Note $A d$ Article III are the main sources of information for replying to the submitted question. Information is obtained by using the methods of ordinary meaning, context, object and purpose and the principles of effectiveness and reasonableness. Such a textual approach is fully in accord with the expectations of the contracting parties as they are expressed in Article 3 (2) of the Understanding on Rules and Procedures. Case law or the "GATT acquis" is beyond the textual approach but plays an important role in interpretation. As it serves predictability and certainty, it is quite in accordance with the expressed expectations of the contracting parties.

There are departures from the textual approach in interpretation of both Articles. They are significant especially in respect to interpretation of Article XX.

158 Rodoljub Etinski, The Interrelationship between the European Convention on Human Rights and the Aarhus Convention, Proceeding of the Novi Sad Faculty of Law, 1/2018, 13.

${ }^{159}$ Fisheries Jurisdiction (United Kingdom v. Island), Merits, Judgment, I.C.J. Reports 1974; Fisheries Jurisdiction (Federal Republic of Germany v. Island), Merits, Judgment, I.C.J. Reports 1974; Gabcikovo-Nagymaros Project (Hungary/Slovakia), Judgment, I.C. J. Reports 1997.

${ }^{160}$ Application of the Interim Accord of 13 September 1995 (the former Yugoslav Republic of Macedonia v. Greece), Judgment of 5 December 2011, I.C.J. Reports 2011.

${ }^{161}$ Gabcikovo-Nagymaros Project (Hungary/Slovakia), Judgment, I.C. J. Reports 1997, para. 142. 
Article III which governs national treatment is applied in an unlimited number of different situations, but it always addresses their abiding elements: comparison of imported and domestic products and a comparison of the fiscal and non-fiscal treatment of them. The objectives of Article XX, such as protection of public morals, life and health or exhaustible natural resources, are mutable over time and require evolutionary interpretation and a search for information in sources which are not necessary the expressions of intention of the contracting parties. The nature of the paragraphs of Article XX escapes the strict textual approach. The broadest scale of means of interpretation, which has gone far away beyond the textual approach, is used for interpretation of the clause "exhaustible natural resources" in Article XX (g). The textual approach and its basic means - the ordinary meaning - does not suffice also interpretation of some terms of crucial importance, such as "like" in Article III:2 and 4 or "necessary" in Article XX (a), (b) and (d). Judicial reasoning, guided by the principle of good faith and one of its components, the principle of reasonableness is inevitable for the clarification of those terms within the framework of specific facts.

The textual approach together with case law does not secure full consistency in interpretation. The choice of various means of interpretation which are applied to interpretation of the same term or the attribution of more weight to one than to another means has resulted in different clarifications. Thus, the ordinary meaning, case law and the 1970 Working Party Report, treated as the subsequent practice of the contracting parties in the application of the GATT 1947 led to a clarification of the term "like" in Article III:4. The same means of interpretation, plus the context create a different clarification of the same term. Almost the same means of interpretations are applied to interpretation of the clause "directly competitive and substitutable products" in two cases, but in one the significance is ascribed to the context and the object of the GATT 1994 and in the other case the importance is given to the ordinary meaning. Moving the decisive weight from one means to the other results in different clarifications of the clause.

The disharmony between information, obtained by applying different means, has been resolved in different ways. In some cases a priority is given to some means over another. In another case, the conflict among opposite information coming from different means leads to the existence of two clarifications, one explicated, which stems from one means and another implied by the application of a provision, which arrives from another means. Thus, "arbitrary and unjustifiable discrimination" has been clarified by relying primarily on the preparatory work, but the application of the clause in the same cases discloses another understanding of the clause, inspired by the ordinary meaning method.

It is not easy to identify factors that determine the choice and weight of means of interpretation. More factors can determine the choice and significance of means, such as to the nature of the object of a provision, facts of the case, an argument of 
the party, development in case law, etc. It seems, however, that most choices are inspired by the classic understanding of interpretation of international treaties according to which the purpose of interpretation is to give effect to intention of the parties as they are expressed through the text of a treaty. It might be that the spirit or the general design of the GATT 1994, as derived from its object and purpose, usually governs the choices and weight of means of interpretation.

An interpretative practice has been noted which can be qualified as an over-interpretation. The requirement that determines the relationship between a measure and an objective, as defined by paragraphs (a), (b) and (d) of Article XX, has been split in to two requirements: a measure has to be designed to the achievement of an objective and it has to be necessary for the achievement of an objective. The requirement "designed" does not appear in the text of the paragraphs and it can be consumed by the "necessary" requirement. It seems that an investigation as to whether a measure is designed in reaching an objective may be redundant.

It has already been observed that an articulated theory of interpretation is lacking. ${ }^{162}$ In spite of that, full compliance with interpretative guidance, as established by the ILC in its works of 1966 and after 2014 is recommendable. If the panels and the Appellate Body consistently adhere to the guidance that all available means of interpretation have to be applied in each case, then far less inconsistency would appear in case law.

${ }^{162}$ I. Van Damme, op.cit., 606, 643. supra note 7. 
Др Родољуб М. Еӣински, редовни йрофесор

Универзииетеи у Новом Саду

Правни факулиетеи у Новом Саду

R.Etinski@pf.uns.ac.rs

\section{Критички преглед тумачења чланова III и XX Општег споразума о трговини и царинама из 1994. године}

Сажейак: Панели и Айелационо йело механизма за рещивање сйорова

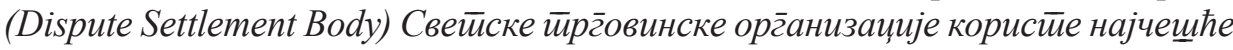
средстива йумачења садржана у стиаву 1 члана 31 Бечке конвениије о йраву

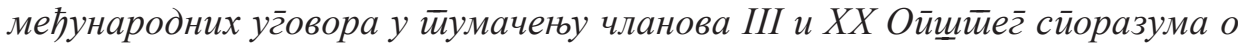
йргоовини и ияаринама из 1994. године. Чланом III је обезбеђен начионални ирретиман за увезену робу. Истираживање је ограничено на сииав 2, који се односи на начионални ииретиман у йогледу йореза и дажбина, и на сйав 4, који се односи на национални йретиман у областиима изван йореза и дажбина. Чланом ХХ су йредвиђени ойщйи изузеци који се односе на јавни морал, животи и здравље, исирйљиве наиионалне ресурсе ийд.

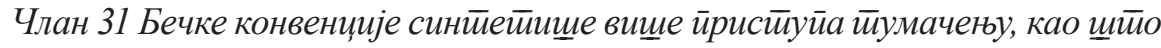
су тиекситуални, ииелеолощки, онај који се своди на уйврђивање намаре

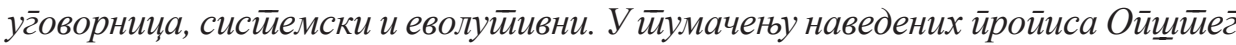

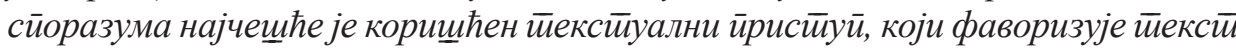

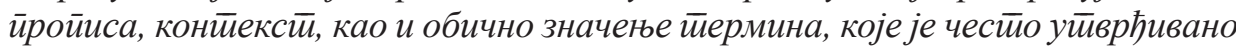

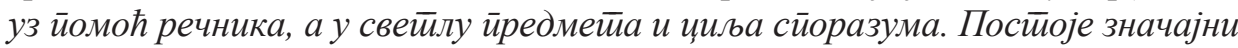
изузетичи који су условљени ириродом ирройсса или ириродом објекйа на који се ирроиис односи. Избором средстиава йумачења или иридавањем одлучујућег̄ значаја неком средстиву стииже са до жељеног̄ резулитайа, о йо је обично резулйай који је имйлициран иредметиом и циљем Ойииеге сйоразума. Важну улог̄у у йумачењу йоред начела добронамерностии има и начело разумностии, које је, уосйалом, један од комйоненайа начела добронамерностии.

Тумачење навдених йройиса Ойщйег̄ сйоразума не иече без иемекоћа и недоумииа. Тако, иостиоји иракса која је означена као ћорсокак, а која би мог̄ла да буде йоследииа вищка йумачења. Уочен је један чудан иример рещавања дисхармоније међу информацијама које стиижу из различийих извора, односно

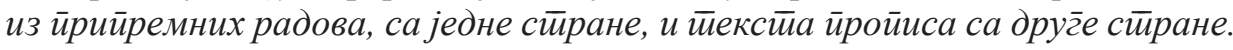

Кључне речи: ииумачење, ГАТТ 1994, национални иирейман, изузеци.

Датум пријема рада: 31.10.2018. 